\title{
Retroauricular Hairline Incision and V-Shaped Incision for Parotidectomy
}

\author{
Ji Song Hong, Dongbin Ahn (D), Gil Joon Lee, and Jin Ho Sohn \\ Department of Otolaryngology-Head and Neck Surgery, School of Medicine, Kyungpook National University, Daegu, Korea
}

후이개 모발선 절개법과 $\mathrm{V}$ 형 절개법을 이용한 이하선 절제술의 비교

홍지송 · 안동빈 · 이길준 · 손진호

경북대학교 의과대학 이비인후-두경부외과학교실

Received October 6, 2020

Revised November 18, 2020

Accepted November 22, 2020

Address for correspondence

Dongbin Ahn, MD

Department of Otolaryngology-

Head and Neck Surgery,

School of Medicine,

Kyungpook National University,

130 Dongdeok-ro, Jung-gu,

Daegu 41944, Korea

Tel $+82-53-200-5781$

Fax +82-53-200-4524

E-mail godlikeu@naver.com
Background and Objectives There have not been any studies that compared retroauricular hairline (RAH) and V-shaped incisions for parotidectomy. In this regard, we aimed to evaluate the results of RAH and V-shaped incisions.

Subjects and Method Between 2016 and 2019, 81 patients who underwent parotidectomy using RAH $(n=46)$ and V-shaped $(n=35)$ incisions were included in this study. Patient characteristics, tumor profiles, surgical parameters, postoperative complications, and cosmetic results were assessed. Mann-Whitney U test and the chi-squared test were used to inspect differences in continuous and categorical variables between the groups, respectively.

Results In the RAH and V-shaped groups, the patient age was 52.7 and 42.1 years, respectively $(p=0.002)$, and the tumour size was 2.7 and $1.8 \mathrm{~cm}$, respectively $(p<0.001)$. All parotidectomies were successfully completed with no incision extension or major complications. There were no significant differences in surgical parameters and postoperative complications between the two groups. The subjective scar satisfaction scores assessed at 3 months postoperatively were 9.0 and 9.3 in the RAH and $\mathrm{V}$-shaped groups, respectively $(p=0.191)$. The scores of male patients were 8.9 and 9.5 in the RAH and V-shaped groups, respectively, $(p=0.026)$, while those of the female patients were 9.2 and 9.2 , respectively $(p=0.906)$.

Conclusion The RAH and V-shaped incisions yields comparable surgical and cosmetic outcomes, with high patient satisfaction. For male patients, the use of V-shaped incision, if indicated, would provide higher scar satisfaction than the use of RAH incision.

Korean J Otorhinolaryngol-Head Neck Surg 2022;65(1):30-6

Keywords Cosmetics; Parotid neoplasms; Scar; Surgery; Surgical wound.

\section{서 론}

이하선 절제술은 대부분의 이하선 종양에 대한 일차적인 치료 방법으로, 수술 시 가능한 한 안면신경을 보존하면서 병 변을 완전히 제거하는 것이 수술의 기본 원칙이다. ${ }^{1-3)}$ 이를 위 해서는 종양과 안면신경 경로를 포함한 이하선 전체를 충분

This is an Open Access article distributed under the terms of the Creative Commons Attribution Non-Commercial License (https://creativecommons.org/licenses/by-nc/4.0) which permits unrestricted non-commercial use, distribution, and reproduction in any medium, provided the original work is properly cited.
히 노출시키는 것이 필수적이며, 해부학적으로 이하선이 위치 하는 안면부와 경부에 걸쳐 S자 형태의 긴 절개를 갖는 Blair 절개법이 이하선 절제술의 기본 접근법으로 현재까지 가장 널리 사용되고 있다. ${ }^{3-5)}$ 이러한 Blair 절개법은 이하선 절제술 을 위한 이하선 전체의 노출과 필요 시 경부 림프절 절제술을 위한 경부 노출의 측면에 있어서는 매우 큰 장점을 갖지만, 절개 흥터가 안면 및 경부의 드러나는 부위에 위치한다는 단 점이 있다. ${ }^{5-7)}$ 이러한 점을 극복하기 위해 1967년 Appiani는 전이개, 후이개, 그리고 후두 모발선 절개로 구성된 안면거상 
절개법을 통한 이하선 절제술을 소개하였으며, 이 절개법의 경우 후이개 절개부는 이개에 의해, 그리고 후두 모발선 절개 의 경우는 머리카락에 의해 그 흥터가 감춰진다는 점에서 기 존의 Blair 절개에 비해 우수한 미용적 결과를 나타내었다.6-10) 최근에는 더 나아가 이러한 안면거상 절개법을 구성하는 3 부 분의 절개 중 일부를 생략함으로써 보다 국한된 피부 절개로 이하선 절제술을 시행하고자 하는 시도가 계속되고 있으며, 그러한 시도 중 대표적인 것이 후이개 후두 모발선 절개와 $\mathrm{V}$ 형 절개를 이용한 이하선 절제술이라 할 수 있겠다. ${ }^{11-16)}$

후이개 후두 모발선 절개법은 안면거상 절개법의 3 부분 중 전이개 절개를 생략하고 후이개 및 후두 모발선 절개만으로 이루어진 절개법으로, 이를 이용한 이하선 절제술은 2014년 Kim 등에 의해 처음으로 보고되었는데, 기존의 Blair 절개법 이나 안면거상 절개법의 경우와 비교하여 합병증 발생 위험 은 증가시키지 않으면서 수술 후 보다 우수한 미용적 결과를 보였다. ${ }^{12,15)} \mathrm{V}$ 형 절개법의 경우 안면거상 절개법의 3 부분 중 후두 모발선 절개를 생략하고 전이개 및 후이개 절개만으로 이루어진 절개법으로, 이를 처음으로 기술한 2018년 Ahn 등 에서의 초기 연구와 그 후속 연구에 따르면, 이하선 미부에서 기원한 큰 종양의 경우에는 그 적용에 한계가 있었으나, 잘 선 택된 환자에 있어서는 안면거상 절개법과 비교하여 추가적인 합병증 발생의 위험 없이 보다 우수한 술후 미용적 결과를 얻을 수 있음을 확인하였다. ${ }^{13,14)}$

이처럼 현재까지 진행된 미용적 이하선 절제술에 대한 연 구들을 살펴보면, Blair 절개법과 안면거상 절개법의 비교 연 구가 대부분이고, 최근 일부 연구에서 안면거상 절개법과 후 이개 후두 모발선 절개법, 그리고 안면거상 절개법과 $\mathrm{V}$ 형 절 개법을 비교 분석하였으나, 안면거상 절개법보다 한 단계 발 전된 절개법인 후이개 후두 모발선 절개법과 $\mathrm{V}$ 형 절개법 사 이의 직접 비교연구는 아직까지 보고된 바가 없다. $2,4,7,12,14,15)$ 이에 저자들은 후이개 후두 모발선 절개법과 $\mathrm{V}$ 형 절개법을 이용한 이하선 절제술의 결과를 비교 분석하여, 이하선 절제 술 후 환자의 미용적 만족도를 높일 수 있는 가장 적절한 절 개법은 무엇인지 확인해보고자 하였다.

\section{대상 및 방법}

\section{대 상}

본 연구는 2016년 6월 2019년 12월까지 한 명의 두경부 외 과의에 의해 시행된 이하선 절제술 중 후이개 후두 모발선 절 개법 또는 $\mathrm{V}$ 형 절개법을 이용한 81예를 대상으로, 소속 기관 의 임상시험심사위원회의 승인을 받아 후향적으로 진행되었 다(IRB No. 202006015). 모든 예에서는 수술 전 종양의 양악
성 여부 및 침범 정도를 확인하기 위한 초음파 및 초음파 유도 하 세침흡인검사, 그리고 경부 전산화단층촬영이 시행되었다. 상기 검사에서 이하선 악성종양의 가능성이 있거나 림프절 절제술이 필요할 것으로 생각되었던 경우 Blair 절개법이나 안면거상 절개법을 이용하였기에 본 연구에서는 제외되었다.

후이개 후두 모발선 절개법 또는 $\mathrm{V}$ 형 절개법의 선택의 경 우 절개 흥터에 대한 환자의 미용적 요구 정도 및 종양의 위 치에 따라 결정되었는데, 이전 연구를 바탕으로 이하선을 크 게 4개의 구획으로 나누었을 때, 후이개 후두 모발선 절개법 의 경우 이하선 중앙과 하부에 위치한 종양에서, 그리고 V형 절개법의 경우 이하선 상부와 전방부에 위치한 경우 주로 사 용되었다. ${ }^{13)}$

\section{이하선 절제술의 술기}

모든 수술은 전신마취하에서 2.5배 확대경을 착용한 상태 의 직접 시야에서 진행되었다. 환자를 앙와위 자세로 위치시 킨 후 어깨 받침대를 이용해 경부가 신전될 수 있도록 하였으 며, 환자의 머리를 건측으로 회전시켰다. 이후 후두부 모발 일부를 깎아 후이개 및 후두부 모발선 절개에 방해가 되지 않도록 하였다.

후이개 후두 모발선 절개는 후이개구(retroauricular sulcus) 의 하단에서 시작해 외이도 높이의 후이개구 중간 지점까지 상방으로 진행한 다음, 후하방으로 방향을 바꾸어 모발선을 따라 이어지도록 하였다(Fig. 1A). 피부 피판은 흥쇄유돌근 의 표면을 따라 전하방으로 접근하여 이하선 피막을 따라 진 행하였으며, 광경근이 확인되는 지점부터는 광경근의 아래쪽 표면을 따라 피판을 거상하여, 종양을 포함한 이하선 전체가 노출되도록 하였다.

$\mathrm{V}$ 형 절개법의 경우 이주연골 전방에서 시작하여 전이개 피부 주름선을 따라 아래로 진행하였으며, 귓볼에 도달한 후 후상방으로 곡선을 그리며 후이개 방향으로 진행하여 외이도 의 후방연장선 높이까지 연결하였다(Fig. 1B). V형 피부절개 의 전방, 하방, 그리고 후방으로 피판을 거상하여 이하선 및 흥쇄유돌근의 전방경계를 노출하였으며 귓볼이 이하선에 부 착된 부분을 분리하여 위쪽으로 거상하였다. 이후 이하선 피 막 및 광경부 하부 층을 따라 피판을 거상하여 종양을 포함 한 이하선 전체를 노출하였다.

이후 안면신경의 노출부터 종양 제거의 과정은 두 절개법 에서 동일하게 진행되었다. 안면신경의 주가지는 고실유돌열 (tympanomastoid fissure)의 내하측으로 박리해 나가면서 확 인하였으며, 주가지 확인 후 종양과 상관관계가 있는 나머지 안면신경 분지들을 주의하여 박리하면서 $0.5 \sim 1.0 \mathrm{~cm}$ 의 절제 연을 두고 종양을 제거하였다. 종양 제거 후에는 후이개 후두 

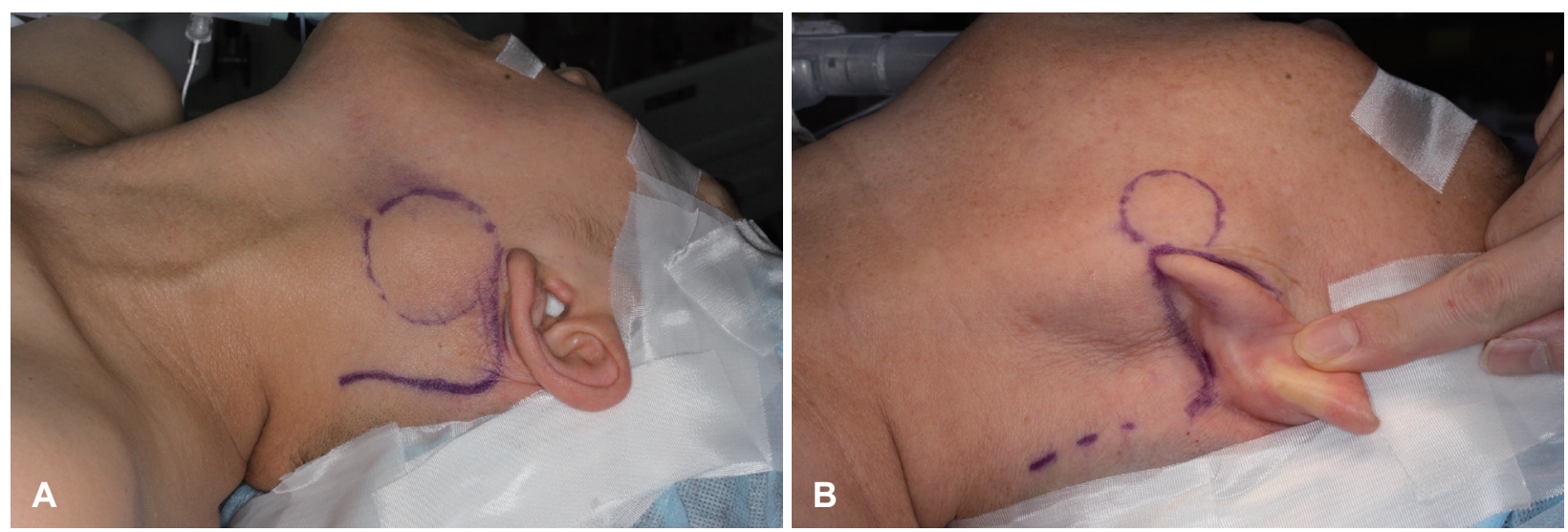

Fig. 1. Incision lines of retroauricular hairline (A) and V-shaped (B) incisions.

모발선 절개법의 경우 후두 모발 절개선의 가장 후하방에 음 압 배액관을 거치시켰으며, V형 절개법의 경우 후이개 절개 선의 가장 후방에 음압 배액관을 거치시킨 후 4-0 Vicryl (Ethicon Inc., Somerville, NJ, USA)과 nylon 실을 이용하 여 피부봉합을 시행하였다. 봉합은 수술 후 5 7일째에 제거 하였다.

\section{평가 항목 및 통계학적 분석}

대상 환자의 인구통계학적 자료와 함께 종양의 크기, 위치, 마취 시작부터 종료까지의 총 수술 시간, 술중 의도치 않은 종양의 파열, 수술 후 총 배액량 및 배액관의 거치 기간에 대 해 평가하였다. 술후 최종 병리조직검사 결과 및 절제연의 상 태에 대해 확인하였으며, 합병증으로는 피부 피판의 괴사, 혈 종, 장액종, 술중 확인된 안면신경의 손상, 술후 실제 발생한 안면신경마비, 타액 누공, 그리고 임상적 Frey 증후군 발생에 대해 조사하였다. 절개 흥터에 대해서는 술후 3 개월째 절개 부위에 대한 환자의 주관적 만족도를 visual analog scale (VAS)을 이용하여 0 10점까지 측정하는 한편, 흥터 소견을 혈관 증식, 착색, 유연성, 그리고 높이 등의 항목을 통해 점수 화하는 Vancouver Scar Scale(VSS)을 이용하여 각 환자의 흥터의 상태를 준객관적(semi-objective)으로 평가하고자 하 였다.

통계학적 분석은 SAS version 9.4(SAS institute Inc., Cary, $\mathrm{NC}, \mathrm{USA}$ ) 프로그램을 이용하였다. 연속형 변수는 평균(mean) 과 범위(range)로 표시하였으며, 비모수 검정법인 Mann-Whitney U test를 이용하여 양 군 간의 통계적 차이를 분석하였다. 범주형 변수에 대해서는 chi-square test 또는 Fisher's exact test를 사용하여 각 변수에 대한 양 군 간의 통계적 차이를 분 석하였다. 유의 수준은 각 항목에서 0.05 의 $p$ 값을 기준으로 이보다 작은 값을 가질 때 통계학적으로 유의한 것으로 판단 하였다.

\section{결 과}

\section{환자 및 종양의 입상병리적 소견}

전체 81명의 환자 중 후이개 후두 모발선 절개를 시행받은 환자는 46 명, $\mathrm{V}$ 형 절개를 시행받은 환자는 35 명이었다. 대상 환자들의 평균 연령은 후이개 후두 모발선 절개군에서 52.7 세, V형 절개군에서 42.1세로, V형 절개군에서 통계학적으로 유의하게 낮았으나 $(p=0.002)$, 성별이나 안면신경과의 관계에 따른 종양의 위치에 있어서는 양 군 간에 유의한 차이를 보이 지 않았다. 다만 종양의 위치를 크게 4 개의 구획으로 나누어 분석하였을 때, 후이개 후두 모발선 절개군에 있어서는 종양의 위치가 모두 이하선 중앙부(37.0\%) 또는 하부(63.0\%)인 것에 비하여, V형 절개군에서는 그 위치가 이하선 전방부(42.8\%), 중앙부(31.4\%), 그리고 상부(22.9\%)의 순서로 분포하였으며 하부에 위치한 경우는 오직 1 예(2.9\%)뿐이었다 $(p<0.001)$. 이 하선 종양의 평균 크기는 후이개 후두 모발선 절개군에서 2.7 $\mathrm{cm}, \mathrm{V}$ 형 절개군에서 $1.8 \mathrm{~cm}$ 로, 후이개 후두 모발선 절개군에 서 통계학적으로 유의하게 종양의 크기가 컸다 $(p<0.001)$. 두 군 모두에서 가장 흔한 최종 진단은 다형선종이었다(Table 1).

\section{수술 결과}

이하선 절제 범위를 천엽부분 절제술(partial-superficial parotidectomy), 심엽부분절제술(partial-deep parotidectomy), 그리고 이하선 아전절제술(sub-total parotidectomy) 등으로 구분하였을 때, 그 분포는 두 군 간에 특별한 차이는 없었다. 또한 두 군 모두에서 충분치 않은 수술 시야로 인해 종양을 완전히 제거하지 못하거나 추가적인 절개를 시행해야 했던 경우는 없었으며, 수술 중 의도치 않게 종양이 파열된 경우도 없었다. 마취 시작부터 마취 종료까지의 평균 수술 시 간은 후이개 후두 모발선 절개군에서 99.5 분, $\mathrm{V}$ 형 절개군에 서 97.1분으로 두 군 간에 통계학적 차이는 없었으며, 술후 평 
균 전체 배액량 또한 후이개 후두 모발선 절개군에서 $57.8 \mathrm{~mL}$, $\mathrm{V}$ 형 절개군에서 $58.3 \mathrm{~mL}$ 로 통계학적으로 차이를 보이지 않 았다. 배액관 거치 기간 및 술후 입원 기간 역시 양 군 간에 의미 있는 차이는 보이지 않았다(Table 2).

\section{술후 합병증 및 흥터 만족도}

일시적 안면신경마비는 후이개 후두 모발선 절개군에서 4명 (8.7\%), V형 절개군에서 2명(5.7\%)으로 통계학적인 차이는 없 었으며, 영구적 안면신경마비는 양 군 모두에서 발생하지 않 았다. 그외 혈종 발생, 장액종, 타액 누공, 그리고 임상적 Frey
증후군의 빈도 역시 양군에서 통계학적인 차이를 보이지 않 았다. 후이개 후두 모발선 절개군 1 예에서 피부 피판 첨부의 괴사가 발생하였는데, 피부 누공이 발생한 제 1 새열기형 환자 에서 해당 피부를 포함한 이하선 절제술이 시행된 경우였다 (Table 3).

술후 3 개월 째 VAS을 이용하여 시행한 환자의 주관적인 흥터 만족도 조사에서 후이개 후두 모발선 절개를 사용한 환 자군에서 9.0점, $\mathrm{V}$ 형 절개를 사용한 환자군에서 9.3점으로 두 군 간에 통계학적으로 유의미한 차이는 없었으나, 성별에 따라 술후 미용적 만족도를 분석해 보았을 때 남성에서는 후

Table 1. Baseline patient characteristics

\begin{tabular}{|c|c|c|c|}
\hline Variables & Retroauricular $(n=46)$ & V-shaped $(n=35)$ & $p$-value \\
\hline Age (years) & $52.7(5-82)$ & $42.1(16-74)$ & 0.002 \\
\hline $\operatorname{Sex}(n, \%)$ & & & 0.079 \\
\hline Male & $22(47.8)$ & $10(28.6)$ & \\
\hline Female & $24(52.2)$ & $25(71.4)$ & \\
\hline Mass size $(\mathrm{cm})$ & $2.7(1.2-5.1)$ & $1.8(0.8-3.0)$ & $<0.001$ \\
\hline \multicolumn{4}{|l|}{ Location (n, \%) } \\
\hline By quadrants & & & $<0.001$ \\
\hline Superior & $0(0.0)$ & $8(22.9)$ & \\
\hline Anterior & $0(0.0)$ & $15(42.8)$ & \\
\hline Middle & $17(37.0)$ & $11(31.4)$ & \\
\hline Inferior & $29(63.0)$ & $1(2.9)$ & \\
\hline By facial nerve & & & $>0.999$ \\
\hline Superficial & $43(93.5)$ & $33(94.3)$ & \\
\hline Deep & $3(6.5)$ & $2(5.7)$ & \\
\hline \multicolumn{4}{|l|}{ Final diagnosis after surgery $(n, \%)$} \\
\hline Pleomorphic adenoma & $22(47.8)$ & $25(71.4)$ & \\
\hline Warthin tumor & $19(41.3)$ & $1(2.9)$ & \\
\hline Lymphoma & $0(0.0)$ & $3(8.6)$ & \\
\hline MEC, low or intermediate grade & $2(4.3)$ & $0(0.0)$ & \\
\hline Other benign pathologies & $3(6.5)$ & $4(11.4)$ & \\
\hline Other malignant pathologies & $0(0.0)$ & $2(5.7)$ & \\
\hline
\end{tabular}

Continuous variables are presented as mean (range). MEC: mucoepidermoid carcinoma

Table 2. Surgical outcomes

\begin{tabular}{|c|c|c|c|}
\hline Variables & Retroauricular $(n=46)$ & $V$-shaped $(n=35)$ & $p$-value \\
\hline Surgical extent ( $n, \%)$ & & & 0.801 \\
\hline Partial-superficial parotidectomy & $43(93.5)$ & $32(91.4)$ & \\
\hline Partial-deep parotidectomy & $3(6.5)$ & $2(5.7)$ & \\
\hline Sub-total parotidectomy & $0(0.0)$ & $1(2.9)$ & \\
\hline Exposure failure $(n, \%)$ & $0(0.0)$ & $0(0)$ & - \\
\hline Inadvertent tumor spillage $(\mathrm{n}, \%)$ & $0(0.0)$ & $0(0)$ & - \\
\hline Operating time (min) & $99.5(40-163)$ & $97.1(55-130)$ & 0.973 \\
\hline Drainage amount $(\mathrm{mL})$ & $57.8(6-116)$ & $58.3(7-350)$ & 0.145 \\
\hline Drainage duration (days) & $3.2(1-5)$ & $3.1(2-6)$ & 0.159 \\
\hline Postoperative hospital stay (days) & $4.0(2-6)$ & $4.0(3-7)$ & 0.483 \\
\hline
\end{tabular}

Continuous variables are presented as mean (range) 
Table 3. Postoperative complications

\begin{tabular}{lccc}
\hline \multicolumn{1}{c}{ Variables } & Retroauricular $(\mathrm{n}=46)$ & V-shaped $(\mathrm{n}=35)$ & $\mathrm{p}$-value \\
\hline Facial nerve palsy & & & \\
$\quad$ Transient & $4(8.7)$ & $2(5.7)$ & 0.694 \\
$\quad$ Permanent & $0(0.0)$ & $0(0)$ & - \\
Skin flap necrosis & $1(2.2)$ & $0(0)$ & - \\
Hematoma & $0(0.0)$ & $2(0.7)$ & - \\
Seroma & $2(4.3)$ & $1(2.9)$ & 0.999 \\
Salivary fistula & $2(4.3)$ & $0(0)$ & 0.648 \\
Symptomatic Frey's syndrome & $0(0)$ & $1(2.9)$ & - \\
Hypertrophic scar & $3(6.5)$ & & 0.630 \\
\hline
\end{tabular}

Data are presented as $\mathrm{n}(\%)$
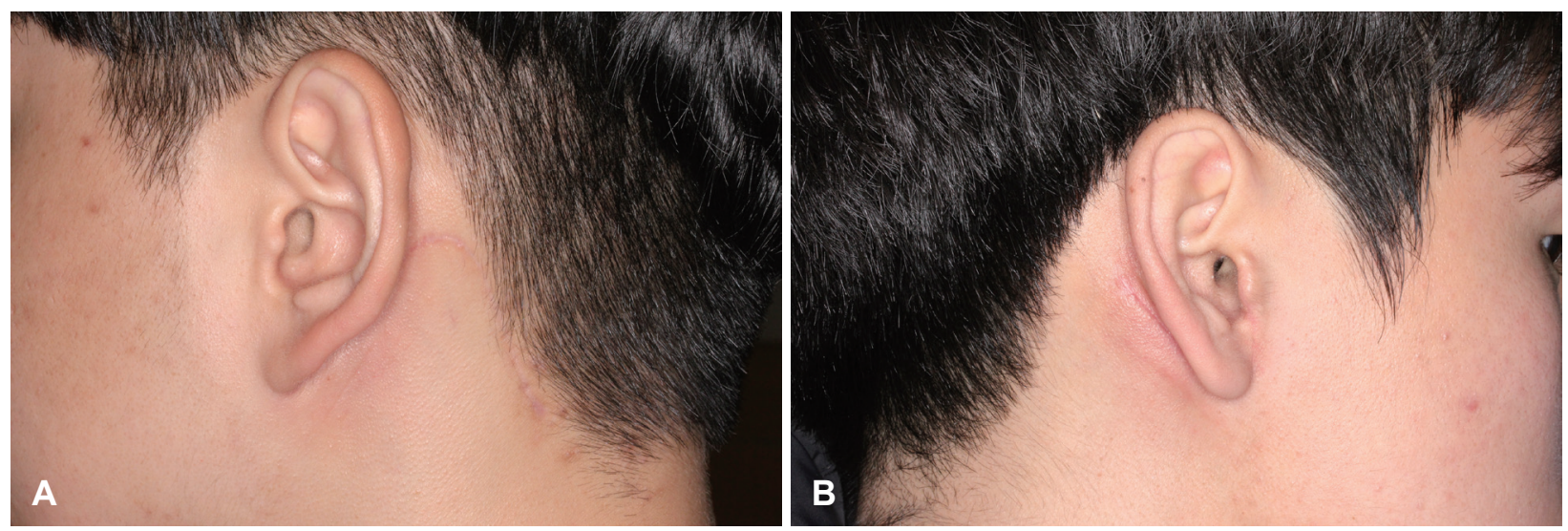

Fig. 2. Photographs of the scar 3 months after parotidectomy in using retroauricular hairline $(A)$ and V-shaped (B) incisions.

Table 4. Postoperative scar assessment

\begin{tabular}{cccc}
\multicolumn{1}{c}{ Variables } & $\begin{array}{c}\text { Retroauricular } \\
(\mathrm{n}=46)\end{array}$ & $\begin{array}{c}\text { V-shaped } \\
(\mathrm{n}=35)\end{array}$ & p-value \\
\hline $\begin{array}{c}\text { Visual analog scale score for subjective scar satisfaction } \\
\text { Overall }\end{array}$ & $9.0(6-10)$ & $9.3(7-10)$ & 0.191 \\
Male & $8.9(8-10)$ & $9.5(9-10)$ & 0.026 \\
Female & $9.2(6-10)$ & $9.2(7-10)$ & 0.906 \\
Vancouver Scar Scale & & & \\
Overall & $0.41(0-3)$ & $0.57(0-3)$ & 0.496 \\
Male & $0.50(0-3)$ & $0.30(0-2)$ & 0.425 \\
Female & $0.33(0-2)$ & $0.68(0-3)$ & 0.186 \\
\hline
\end{tabular}

Continuous variables are presented as mean (range)

이개 후두 모발선 절개군과 $\mathrm{V}$ 형 절개군의 미용적 만족도가 각각 8.9점과 9.5점으로 통계학적으로 유의한 차이를 보였다 $(p=0.026)$ (Fig. 2).

술후 3개월째 Vancouver Scar Scale을 이용한 준객관적인 흥터 평가에서는 후이개 후두 모발선 절개군에서 0.41점, $\mathrm{V}$ 형 절개군에서 0.57 점으로 의미 있는 차이는 없었으며, 그 결과 는 성별에 따른 추가 분석해서도 특별한 차이는 보이지 않았 다(Table 4).

\section{고 찰}

이번 연구에서 저자들은 술전 양성으로 진단된 이하선 종 양에 대해 후이개 후두 모발선 절개법과 $\mathrm{V}$ 형 절개법을 이용 한 이하선 절제술의 결과를 직접 비교해 보았으며, 두 절개법 모두 양성 이하선 종양에 대한 미용적 이하선 절제술의 1차 선택 절개법으로 충분히 적용될 수 있음을 보여주었다.

본 연구에서 이하선 종양의 평균 크기는 후이개 후두 모발 선 절개군에서 $2.7 \mathrm{~cm}, \mathrm{~V}$ 형 절개군에서 $1.8 \mathrm{~cm}$ 로, $\mathrm{V}$ 형 절개 군에서 통계학적으로 유의하게 그 크기가 작은 것으로 나타 났다. 이는 이전 2015년 Kim 등 ${ }^{17)}$ 이나 2015년 Ahn 등하의 연 구에서 변형 Blair 절개법과 변형 안면거상 절개법을 적용한 이하선 종양의 평균 크기가 각각 $2.8 \sim 2.4 \mathrm{~cm}$ 와 $2.6 \sim 2.3 \mathrm{~cm}$ 가량으로 보고된 것과 비교해 보았을 때도, $\mathrm{V}$ 형 절개군에서 의 종양의 크기가 다소 작은 것을 확인할 수 있었다. 저자들 은 이번 연구에서 $\mathrm{V}$ 형 절개군을 선택하는 데 있어 종양의 크 기에 대한 고려는 없었다. 그러나 $\mathrm{V}$ 형 절개법의 경우 이하선 미부보다는 이하선의 상부 혹은 전방부의 노출에 용이하기 때문에, 주로 해당 영역에 위치한 종양에 대해 적용되었으며, 이러한 위치의 경우 이하선 실질 및 그를 덮고 있는 피하조직 
이 상대적으로 얇아 작은 크기의 종양도 조기에 진단될 수 있 었기 때문에 $\mathrm{V}$ 형 절개군에서의 종양의 크기가 다소 작은 것 으로 생각된다. ${ }^{13,14)}$

수술 범위, 수술 중 소견, 수술 시간, 그리고 수술 후 배액 등과 관련된 수술 결과에서는 양 군 간에 특별한 차이가 없 었으며, 술후 합병증에 있어서도 양 군 간에 차이는 없었다. 특히 이하선 종양 수술에 있어 가장 중요한 안면신경 보존과 관련된 결과를 살펴보면, 본 연구에서 후이개 후두 모발선 절개군과 $\mathrm{V}$ 형 절개군에서의 일시적인 안면신경마비의 빈도 는 8.7\%와 5.7\%로, 이전 많은 연구들에서 보고한 5.5 33.8\% 의 빈도에 준하는 결과를 보였으며, 이는 후이개 후두 모발선 절개법과 V형 절개법 모두 기존의 Blair 절개법이나 안면거상 절개법에 비해 특별히 안면신경손상의 위험도를 증가시키지 않는다는 것을 보여주는 결과라 할 수 있다.,5-7,17)

이번 연구에서 술후 3 개월 째 VAS를 이용하여 시행한 환 자의 주관적 흥터 만족도는 후이개 후두 모발선 절개군과 $\mathrm{V}$ 형 절개군 모두에서 평균 9.0점으로 동일하였다. 이러한 결과 를 2015년 연구에서 변형 Blair 절개법과 변형 안면거상 절개 법에서의 주관적 흥터 만족도가 각각 5.7점과 8.5점으로 보 고된 것과 비교해보면, 후이개 후두 모발선 절개법과 $\mathrm{V}$ 형 절 개법 모두 기존의 이하선 수술 절개법에 비해 보다 우수한 미 용적 만족도를 나타낸다고 할 수 있다. ${ }^{4}$ 본 연구에서 술후 미 용적 만족도에 대한 한가지 흥미로운 소견은, 성별에 따른 만 족도 분석을 시행했을 때 남성에서 후이개 후두 모발선 절개 법(8.9점)을 사용한 경우보다 V형 절개법(9.5점)을 사용한 경 우 통계학적으로 유의하게 흥터에 대한 주관적 만족도가 높 았다는 점이다. 이는 여성과는 달리 주로 짧은 모발을 가진 남성 환자에서 비교적 긴 후두 모발선 절개의 흥터가 짧은 모 발에 의해 가려지지 않기 때문에, 동일한 후이개 후두 모발선 절개를 사용한 경우라 하더라도 상대적으로 남성 환자에서의 흥터가 육안적으로 인지하기 쉽기 때문이었을 것으로 사료된 다. ${ }^{13)}$ 동일한 맥락으로 $\mathrm{V}$ 형 절개군의 경우 비록 안면부 전이 개 절개가 육안적으로 인지하기 쉬운 위치에 있으나, 대부분 의 경우 전이개부의 주름선과 일치하기 때문에 술후 3 개월이 지난 시점에서는 크게 두드러지지 않으며, 후두 모발선 절개 자체가 없기 때문에 짧은 모발을 가진 남성 환자에 있어서 그에 따른 미용적 만족도가 보다 크게 작용하였을 것으로 생 각된다.

이번 연구의 한계점으로 가장 중요한 것은 후향적 연구의 특성상 절개법의 선택이 무작위 배정되지 않았기 때문에, 각 절개법의 대상이 되는 환자에 관한 선택 편견이 포함되었다 는 점이다. 특히 본 연구에 포함된 각 절개법의 특성상 후이개 후두 모발선 절개의 경우는 이하선 중앙이나 미부에 위치한
종양에서, 그리고 V형 절개의 경우는 이하선 전부나 상부에 위치한 종양에서 주로 사용되었기 때문에, 본 연구에서 이러 한 종양의 위치 차이가 술후 미용적 결과에 미치는 영향은 평 가하기가 어려운 점이 있다. 하지만 이하선의 다양한 위치에 발생할 수 있는 양성 이하선 종양의 수술적 치료에 있어, 모든 환자에게 일괄적으로 Blair 절개법이나 안면거상 절개법을 적용하기보다는 종양의 위치나 특성을 고려하여 후이개 후 두 모발선 절개법과 V형 절개법을 적절히 선택하여 적용한다 면 해당 환자들에게는 보다 높은 미용적 결과를 제공할 수 있는 좋은 선택사항이 될 수 있을 것이다. ${ }^{18)}$

본 연구 결과를 종합하여 보면 후이개 후두 모발선 절개법 과 $\mathrm{V}$ 형 절개법을 이용한 이하선 절제술은 수술 및 술후 미 용적 평가에 있어 서로 대등한 결과를 보였으며, 이를 바탕으 로 환자의 미용적 요구와 종양의 특성을 고려하여 두 절개법 모두 양성 이하선 종양에 대한 미용적 이하선 절제술의 일차 선택 절개법으로 활용될 수 있을 것으로 사료된다. 특히, 남성 환자에 있어서는 종양의 위치를 고려하여 $\mathrm{V}$ 형 절개법을 적 극 사용함으로써, 수술 후 흥터에 대한 미용적 만족도를 보다 향상시킬 수 있을 것으로 사료되는 바이다.

\section{Acknowledgments}

None.

\section{Author Contribution}

Conceptualization: Dongbin Ahn, Gil Joon Lee, Jin Ho Sohn. Data curation: Ji Song Hong, Dongbin Ahn, Gil Joon Lee. Formal analysis: all authors. Funding acquisition: Gil Joon Lee, Jin Ho Sohn. Investigation: Dongbin Ahn, Gil Joon Lee. Methodology: Ji Song Hong, Dongbin Ahn. Project administration: Dongbin Ahn, Jin Ho Sohn. Supervision: Dongbin Ahn, Gil Joon Lee, Jin Ho Sohn. Visualization: Dongbin Ahn. Writing — original draft: Ji Song Hong, Dongbin Ahn. Writing — review \& editing: Dongbin Ahn, Gil Joon Lee, Jin Ho Sohn.

\section{ORCID}

Dongbin Ahn https://orcid.org/0000-0002-4977-7406

\section{REFERENCES}

1) Buchman C, Stringer SP, Mendenhall WM, Parsons JT, Jordan JR, Cassisi NJ. Pleomorphic adenoma: Effect of tumor spill and inadequate resection on tumor recurrence. Laryngoscope 1994; 104(10):1231-4.

2) Nouraei SA, Al-Yaghchi C, Ahmed J, Kirkpatrick N, Mansuri S, Singh A, et al. An anatomical comparison of Blair and facelift incisions for parotid surgery. Clin Otolaryngol 2006;31(6):531-4.

3) Laccourreye H, Laccourreye O, Cauchois R, Jouffre V, Ménard M, Brasnu D. Total conservative parotidectomy for primary benign pleomorphic adenoma of the parotid gland: A 25-year experience with 229 patients. Laryngoscope 1994;104(12):1487-94.

4) Ahn D, Kim H, Choi JH, Sohn JH. Modified Blair incision versus modified facelift incision combined with sternocleidomastoid muscular flap in parotidectomy. Korean J Otorhinolaryngol-Head Neck Surg 2015;58(1):37-43. 
5) Mantsopoulos K, Koch M, Klintworth N, Zenk J, Iro H. Evolution and changing trends in surgery for benign parotid tumors. Laryngoscope 2015;125(1):122-7.

6) Lohuis PJ, Tan ML, Bonte K, van den Brekel MW, Balm AJ, Vermeersch HB. Superficial parotidectomy via facelift incision. Ann Otol Rhinol Laryngol 2009;118(4):276-80.

7) Grover N, D’Souza A. Facelift approach for parotidectomy: An evolving aesthetic technique. Otolaryngol Head Neck Surg 2013; 148(4):548-56.

8) Ferreria JL, Mauriño N, Michael E, Ratinoff M, Rubio E. Surgery of the parotid region: A new approach. J Oral Maxillofac Surg 1990;48(8):803-7.

9) Appiani E. Handling of a parotidectomy and muscular graft. Prensa Med Argent 1967;54(25):1242-3.

10) Appiani E, Delfino MC. Plastic incisions for facial and neck tumors. Ann Plast Surg 1984;13(4):335-52.

11) Yuen AP. Small access postaural parotidectomy: An analysis of techniques, feasibility and safety. Eur Arch Otorhinolaryngol 2016; 273(7):1879-83.

12) Kim DY, Park GC, Cho YW, Choi SH. Partial superficial parotidectomy via retroauricular hairline incision. Clin Exp
Otorhinolaryngol 2014;7(2):119-22.

13) Ahn D, Sohn JH, Lee GJ. Feasibility of a new V-shaped incision for parotidectomy: A preliminary report. Br J Oral Maxillofac Surg 2018;56(5):406-10.

14) Kwak JH, Lee JY, Lee GJ, Sohn JH, Ahn D. Comparison of the facelift incision versus V-shaped incision for parotidectomy. Korean J Otorhinolaryngol-Head Neck Surg 2019;62(1):43-8.

15) Jung YJ, Lee GJ, Sohn JH, Ahn D. Partial superficial parotidectomy via retroauricular hairline incision. Korean J Otorhinolaryngol-Head Neck Surg 2018;61(1):42-6.

16) Jo MG, Lee DJ, Cha W. A modified V-shaped incision combined with superficial musculo-aponeurotic system flap for parotidectomy. Acta Otolaryngol 2019;139(2):178-83.

17) Kim MK, Ji YB, Song CM, Lee SH, Kim KR, Tae K. Comparison of modified Blair incision and modified facelift incision in parotidectomy. Korean J Otorhinolaryngol-Head Neck Surg 2015; 58(5):337-40.

18) Zhang Q, Yang Y, Yang P, Tan Y, Liu X, Xiong B, et al. Cosmetic approach selection in parotidectomy for benign parotid gland tumour according to its location. J Plast Reconstr Aesthet Surg 2020;73(5):921-6 